\title{
ANALISIS KECAKAPAN BERPIKIR RASIONAL : DAMPAK DARI PENERAPAN METODE SOCRATES DAN KECERDASAN MAJEMUK SISWA
}

\section{ANALYSIS OF RATIONAL THINKING SKILLS: IMPACT OF THE APPLICATION OF SOCRATES METHOD AND STUDENT COMPOUND INTELLIGENCE}

\author{
Zhuhria Islami Martunus $^{a}$, Netriwati ${ }^{b}$, Dona Dinda Pratiwi ${ }^{c}$, Fadly Nendra ${ }^{d}$ \\ ${ }^{a}$ Pendidikan Matematika Universitas Islam Negeri Raden Intan Lampung \\ Jalan Endro Suratmin Sukarame Bandar Lampung, Indonesia \\ zhuhriamartunus25@gmail.com \\ ${ }^{\mathrm{b}}$ Pendidikan Matematika Universitas Islam Negeri Raden Intan Lampung \\ Jalan Endro Suratmin Sukarame Bandar Lampung, Indonesianetriwati@ radenintan.ac.id \\ ${ }^{\mathrm{c}}$ Pendidikan Matematika Universitas Islam Negeri Raden Intan Lampung \\ Jalan Endro Suratmin Sukarame Bandar Lampung, Indonesia donadinda@ radenintan.ac.id \\ ${ }^{\mathrm{d}}$ Pendidikan Matematika Universitas Islam Negeri Raden Intan Lampung \\ Jalan Endro Suratmin Sukarame Bandar Lampung, Indonesia fadlynendra@ gmail.com ${ }^{4}$
}

\begin{abstract}
ABSTRAK
Tujuan penelitain ini yaitu untuk mengetahui dampak kecakapan berpikir rasional antara siswa yang diberikan metode socrates dengan siswa yang diberikan metode konvensional, mengetahui dampak antara siswa yang memiliki kecerdasan majemuk terhadap kecakapan berpikir rasional siswa, dan mengetahui Interaksi antara metode socrates dengan kecerdasan majemuk terhadap kecakapan berpikir rasional. Metode penelitian ini penelitian kuantitatif dengan jenis penelitian eksperimen. Jenis eksperimen penelitian ini adalah Quasi Eksperimental Design. Teknik pengambilan data yang digunakan angket dan tes. Berdasarkan analisis nilai posttest dan skor angket dengan uji anava dua jalur menghasilkan adanya dampak kecakapan berpikir rasional antara siswa yang diberikan metode socrates dengan siswa yang diberikan metode konvensional dengan persentase siswa yang diberikan metode socrates sebesar 53,10\%, dan siswa yang diberikan metode konvensional sebesar 46,89\%, Adanya dampak antara siswa yang memiliki kecerdasan majemuk terhadap kecakapan berpikir rasional siswa, dan tidak ada interaksi antara sehingga yang bersangkutan mampu menghadapi dan memecahkan masalah kehidupan yang metode socrates dengan kecerdasan majemuk terhadap kecakapan berpikir rasional siswa.
\end{abstract}

Kata Kunci: Metode Socrates; Kecakapan Berpikir Rasional;dan Kecerdasan Majemuk.

\section{ABSTRACT}

The purpose of this study is to determine the impact of rational thinking skills between students given the method of socrates with students given conventional methods, knowing the impact between students who have a compound intelligence on proficiency Rational thinking students, and knowing the interactions between Socrates method with a compound intelligence to rational thinking skills. This method of research is quantitative research with experimental research types. This type of research experiment is Quasi Experimental Design. Data retrieval techniques used by polls and tests. Based on the analysis of the Posttest value and the poll score with two-lane Anava test resulted in the impact of rational thinking skills between students given Socrates method with students given conventional methods with the percentage of students who Given the method of Socrates by $53.10 \%$, and the student given the conventional method of $46.89 \%$, the impact between students who have a compound intelligence to the rational thinking skills of students, and there is no interaction between the Concerned is able to face and solve the problem of life that Socrates method with a compound intelligence to the rational thinking skills of students. 
Keywords: Socrates method; Rational Thinking Skills; and Multiple Intelligence.

\section{Pendahuluan}

Merancang sumber daya manusia merupakan kunci utama untuk memetik kejayaan pada era yang serba kompetisi ini (Nasution, 2019). Pendidikan pula mampu mengembangkan potensi siswa yang dihadapinya (Ramli, 2015). Proses pendidikan tidak dapat dipisahkan dari poses belajar (Yasin \& Netriwati, 2019), Sebab perkembangan ilmu pengetahuan dan teknologi yang semakin pesat menuntut siswa untuk dapat mengembangkan kecakaapan berpikir rasionalnya (Assapari, 2014; Budiman, 2017). Sehingga kecakapan berpikir rasional kepiawaian dasar matematika perlu dimiliki siswa (Salamah \& Amelia, 2019; Sinta, 2017) karena kecakapan berpikir rasional dari berpikir kompleks yang dapat dilatih siswa (Estuningsih, 2016; Zulva, 2016). Adapun dalam berpikir rasional siswa dituntut menggunakan data, perinsip, logika, menentukan sebab akibat dan menarik kesimpulan (R. N. Astuti, 2012).

Metode socrates sebagai merode yang didalamnya terjadi dialog antara guru dengan siswa yang memuat pertanyaanpertanyaan kritis dengan tujuan membangun pola pikir siswa, menuntun pada suatu penemuan baru, membuat siswa ingin tahu lebih jauh dan memahami lebih dalam, serta menguji validitas atau kebenaran keyakinan siswa dan membuat kesimpulan yang benar pada suatu objek (Nurjannah, 2014). Kelebihan metode Socrates(Yulisa dkk., 2015): a) Merangsang untuk Berpikir Kritis. b) Siswa dengan persiapan yang bagus akan mampu mengikuti pembelajaran dengan baik karena mampu mempertimbangkan implikasi yang lebih luas. c) Menumbuhkan
Motivasi Dan Keberanian Dalam Mengemukakan Pendapat Dan Pikiran Sendiri. d) Memupuk rasa percaya diri sendiri karena memberikan tanggapan yang berasal dari pemikiran. e) Memupuk Lingkungan Belajar Yang Interaktif dan Menarik dan f) menumbuhkan kelas yang disiplin.

Kecakapan berpikir rasional menuntut siswa untuk memahami dan membuat keputusan berdasarkan faktafakta yang diungkap dari lapangan sehingga diperoleh suatu pemecahan persoalan (Nurohman, 2006). Berpikir rasional meliputi pengumpulan fakta-fakta, pengolahan informasi sampai padapengambilan keputusan (P. D. Astuti, 2017). kecerdasan majemuk tidak bergantung ditingkat tertentu dan terbatas pada saat seorang lahir (Sholeh, 2016). Setiap orang mengembangkan kecerdasan dengan beragam cara (Madyawati \& Si, 2016). Kecerdasan majemuk yang dipaparkan oleh Gardner. Kecerdasan majemuk tersebut antara lain; kecerdasan logis-matematik, kecerdasan interpersona, dan kecerdasan linguistic (Elfiadi, 2017; Septiana \& Ikhsan, 2017).

Salah satu alternatif yang membuat pembelajaran diduga mampu mengoptimalkan siswa supaya mempunyai kepiawaian yang baik dalam berpikir rasional dengan melakukan beragam proses dalam pembelajaran (Kecerdasan, 2017), diantaranya dengan memanfaatkan metode Socrates (Cahyono dkk., 2015; Sholihah \& Shanti, 2017). Penerapan metode socrates pernah diteliti oleh peneliti sebelumnya diantaranya dilakukan (Nurjannah, 2014), perbedaan dalam peneitian ini adalah yaitu terdapat pada pokok bahasan pembelajaran 
(pembelajran Fisika), Penelitian lainnya juga dilakukan oleh (Ernawati \& Nasir, 2018) terhadap hasil belajar statistik dasar siswa, Penelitian lainnya dilakukan oleh (Syukur dkk., 2019). Perbedaan adalah peningkatan kemempuan berpikir kretif matematis pada siswa menggunakan metode socrates. Berdasarkan beberapa penelitian yang telah dilakukan terdahulu, memiliki perbedaan dan pembaruan dari setiap penelitian yang telah dilakukan Perbedaan dan pembaruan pada penelitian ini adalah pada peninjauan terhadap kecerdasan majemuk yang dimiliki siswa.

\section{Metode Penelitian}

Penelitian dilaksanakan di SMPN

33 Bandar Lampung. Adapun waktu penelitian dilaksanakan pada semester genap tahun ajaran 2019/2020. Penelitian ini menggunakan metode penelitian kuantitatif dengan jenis penelitian eksperimen. Peneliti menggunakan jenis penelitian eksperimen karena penulis ingin mencari pengaruh treatment (perlakuan) tertentu.

Jenis eksperimen yang peneliti gunakan pada penelitian ini adalah Quasi Eksperimental Design. Mempunyai kelas kontrol, namun kelas tersebut tidak dapat berfungsi sepenuhnya untuk mengontrol variabel-variabel luar yang mempengaruhi pelaksanaan eksperimen.Pada kelas eksperimen akan diberikan perlakuan khusus yaitu proses pemebelajaran dilaukan dengan menerapkan pembelajaran socrates, sedangkan kelas pembanding dilakukan dengan metode konvesional.

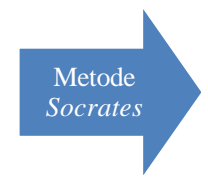

Desain yang digunakan adalah desain faktorial $2 \times 3$, dengan maksud ingin mengetahui keterkaitan variabel bebas dan

\section{Kecakapan Berpikir Rasional}

variabel terikat, dapat dilihat pada Table 3.1 sebagai berikut.

Tabel 1

Desain Faktorial Penelitian

\begin{tabular}{cccc}
\hline Metode Pembelajaran $\left(\mathrm{A}_{\mathrm{i}}\right)$ & \multicolumn{3}{c}{ Kecerdasan Majemuk $\left(\mathrm{B}_{\mathrm{j}}\right)$} \\
& $\begin{array}{c}\text { Kecerdasan } \\
\text { Matematis-logis } \\
\left(\mathrm{B}_{1}\right)\end{array}$ & $\begin{array}{c}\text { Kecerdasan } \\
\text { Interpersonal }\left(\mathrm{B}_{2}\right)\end{array}$ & $\begin{array}{c}\text { Kecerdasan } \\
\text { Linguisik }\left(\mathrm{B}_{3}\right)\end{array}$ \\
\hline Socrates $\left(\mathrm{A}_{1}\right)$ & $\left(\mathrm{A}_{1} \mathrm{~B}_{1}\right)$ & $\left(\mathrm{A}_{1} \mathrm{~B}_{2}\right)$ & $\left(\mathrm{A}_{1} \mathrm{~B}_{3}\right)$ \\
Konvensional $\left(\mathrm{A}_{2}\right)$ & $\left(\mathrm{A}_{2} \mathrm{~B}_{1}\right)$ & $\left(\mathrm{A}_{2} \mathrm{~B}_{2}\right)$ & $\left(\mathrm{A}_{2} \mathrm{~B}_{3}\right)$ \\
\hline
\end{tabular}

Teknik sampling yang akan digunakan dalam penelitian ini adalah cluster random sampling. Sampel penelitian ini terdiri dari 2 kelas yaitu satu kelas eksperimen dengan menggunakan metode socrates dan satu kelas menggunakan metode ekspositori. Teknik pengambilan data yang digunakan tes, angket dan wawancara. Teknik analisis data yang digunakan menguji hipotesisi penelitian adalah uji anava dua jalur, sebelum melakukan uji hipotesis, dilakukan uji prasyarat yaitu uji normalitas dan uji homogenitas.

\section{Hasil Dan Pembahasan}

Berikut merupakan hasil dari analisis uji normalitas kecakapa berpikir rasional : 
Tabel 2

Uji Normalitas Kecakapan Berpikir Rasional

\begin{tabular}{cccc}
\hline Kelas & $\boldsymbol{l}_{\text {hitung }}$ & $\boldsymbol{l}_{\text {tabel }}$ & kesimpulan \\
\hline Kontrol & 0,122 & 0,159 & $H_{0}$ diterima \\
Eksperimen & 0,108 & 0,161 & $H_{0}$ diterima \\
\hline
\end{tabular}

Berdasarkan Tabel 4.5, diperoleh hasil perhitungan pada kelas control yaitu $l_{\text {hitung }}=0,122$ dengan $\quad l_{\text {tabel }}=0,159$ .Perhitungan pada kelas eksperimen yaitu $l_{\text {hitung }}=0,108$ dengan $\quad l_{\text {tabel }}=0,161$ dari hasil perhitungan uji normalitas pada kelas kontrol dan kelas eksperimen dapat dilihar bahwa $l_{\text {hitung }} \leq l_{\text {tabel }}$ yang berarti $H_{0}$ diterima. Maka dapat disimpulkan bahwa kelas kontrol dan eksperimen merupakan sampel yang berasal dari populasi yang berdistribusi normal.

Uji normalitas kecerdasan majemuk pada kelas kontrol dan eksperimen. Pada penelitian ini telah dikelompokkan menjadi tiga kategori yakni kecerdasan logismatematis, kecerdasan interpersonal dan kecerdasan linguistik, berikut hasil dari data uji normalitas kecerdasan majemuk (kecerdasan logis-matematis, interpersonal dan linguistik)

Tabel 3

Uji Normalitas Kecerdasan Majemuk (Kecerdasan Logis-Matematis, Kecerdasan Interpersonal dan Kecerdasan Linguistik)

\begin{tabular}{cccccc}
\hline Kategori & & Kelas & $l_{\text {hitung }}$ & $l_{\text {tabel }}$ & kesimpulan \\
\hline & L-M & Kontrol dan Eksperimen & 0,131 & 0,2 & $H_{0}$ diterima \\
& I & Kontrol dan Eksperimen & 0,126 & 0,165 & $H_{0}$ diterima \\
Kecerdasan Majemuk & L & Kontrol dan Eksperimen & 0,077 & 0,206 & $H_{0}$ diterima \\
\hline
\end{tabular}

Berdasarkan tabel tersebut, di dapatkan hasil perhitungan pada kelas kontrol dan eksperimen yakni $l_{\text {hitung }}=0,131$ dan $l_{\text {tabel }}=0,2$ pada pengujian normalitas yang dilakukan untuk kecerdasan logis matematis, hasil perhitungan pada kelas kontrol dan eksperimen yakni $l_{\text {hitung }}=$ 0,126 dan $l_{\text {tabel }}=0,165$ pada pengujian normalitas yang dilakukan untuk kecerdasan interpersonal dan menghasilkan perhitungan pada kelas kontrol dan eksperimen yakni $l_{\text {hitung }}=0,077$ dan $l_{\text {tabel }}=0,206$ pada pengujian normalitas yang dilakukan untuk kecerdasan Lingustik.

Hasil perhitungan tersebut menyatakan $l_{\text {hitung }} \leq l_{\text {tabel }}$ yang berarti $\mathrm{H}_{0}$ diterima. Berdasarkan pengujian uji normalitas kecerdasan majemuk dapat disimpulkan bahwa kelas kontrol dan kelas eksperimen merupakan sampel yang berasal dari populasi yang berdistribusi normal. Hasil analisis dari data uji homogenitas kecakapan berpikir rasional pada kelas kontrol dan kelas eksperimen sebagai berikut: 
Tabel 4

Uji Homogenitas Kecakapan Berpikir Rasional

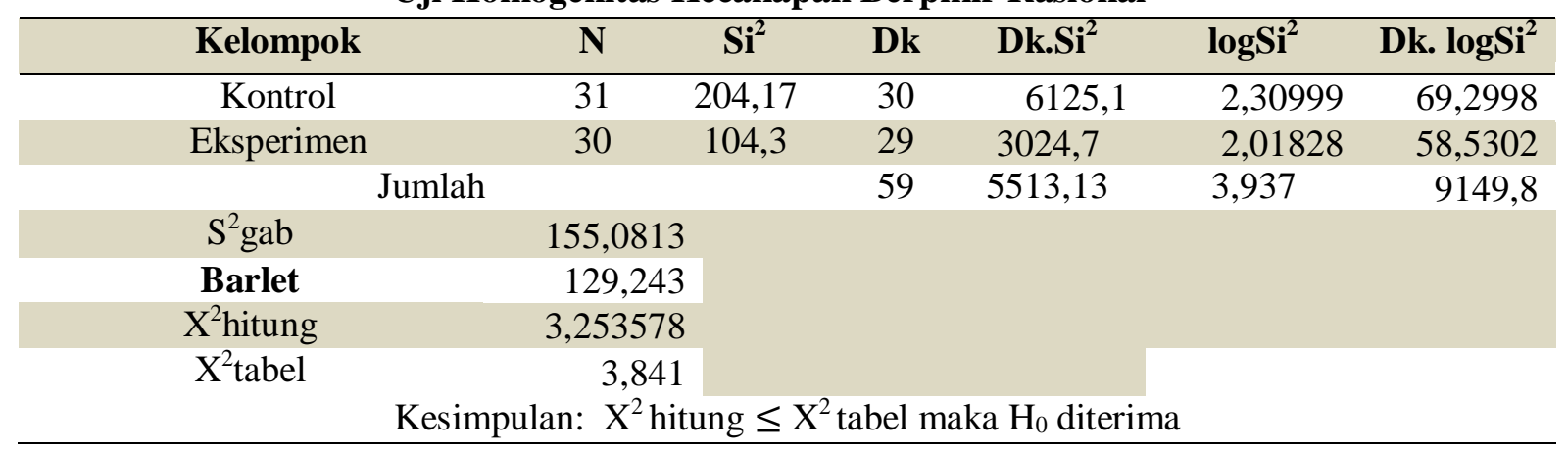

Berdasarkan data yang diperoleh bahwa hasil analisis data uji homogenitas kecakapan berpikir rasional didapatkan $X^{2}$ hitung $=3,253$ dengan $X_{\text {tabel }}^{2}=3,841$. Terlihat bahwa $X^{2}$ hitung $\leq X^{2}$ tabel maka $H_{0}$ diterima, yang artinya kedua sampel berasal dari populasi yang sama (homogen). Hasil analisis data uji hipotesis kecerdasan majemuk (kecerdasan logis matematis, interpersonal dan linguistik) adalah sebagai berikut:

Tabel 5

Uji Homogenitas Kecerdasan Majemuk (kecerdasan logis matematis, interpersonal dan linguistik)

\begin{tabular}{|c|c|c|c|c|c|c|}
\hline Kelompok & $\mathbf{n}$ & $\mathrm{Si}^{2}$ & Dk & Dk.si ${ }^{2}$ & $\operatorname{Logsi}^{2}$ & ${ }^{D k} \cdot \operatorname{logsi} i^{2}$ \\
\hline LM & 18 & 125,647 & 17 & 2136 & 2,09915 & 35,6856 \\
\hline $\mathrm{L}$ & 17 & 185,441 & 16 & 2967,06 & 2,26821 & 36,2913 \\
\hline I & 26 & 151,1154 & 25 & 3777,885 & 2,17931 & 54,4827 \\
\hline Jumlah & 61 & 462,204 & 58 & 8880,94 & 6,54667 & 126,46 \\
\hline S2gab & 153,1197 & & & & & \\
\hline $\log \mathrm{s} 2 \mathrm{gab}$ & 2,185031 & & & & & \\
\hline B & 126,7318 & & & & & \\
\hline X2htg & 0,626761 & & & & & \\
\hline Xtabel & $\begin{array}{r}5,991 \\
\text { Kesimpulan: }\end{array}$ & hitung $\leq X$ & tabel & $\mathrm{ka} \mathrm{H}_{0}$ diter & & \\
\hline
\end{tabular}

Hasil analisis data uji homogenitas kecerdasan majemuk (kecerdasan logis matematis, interpersonal dan linguistik) diperoleh $\mathrm{X}^{2}$ hitung $=0,626$ dengan $\mathrm{X}_{\text {tabel }}^{2}=$ 5,991 dapat dilihar bahwa $X^{2}{ }_{\text {hitung }} \leq X^{2}$ tabel maka $\mathrm{H}_{0}$ diterima, yang artinya ketiga kategori kecerdasan majemuk (kecerdasan logis matematis, interpersonal dan linguistik) berasal dari populasi yang sama (homogen). Setelah melakukan uji normalitas dan homogenitas pada sempel berdistribusi normal dan homogen, maka dilakukan uji analisis variansi dua jalur dengan sel tak sama. Berikut merupakan hasil analisis data pada uji analisis variansi dua jalur sel tak sama: 
Tabel 6

Analisis Variansi Dua Jalur Sel Tak Sama

\begin{tabular}{lccccc}
\hline \multicolumn{1}{c}{ Sumber } & JK & Dk & RK & F $_{\text {obs }}$ & $\boldsymbol{F}_{\text {tabel }}$ \\
\hline Penerapan pembelajaran(A) & 1063 & 1 & 1063 & 7,73741 & 4,0162 \\
Kecerdasan majemuk (B) & 1584,65 & 2 & 792,324 & 5,7672 & 3,16499 \\
Ineraksi (AB) & 176,57 & 2 & 88,285 & 0,64261 & 3,16499 \\
Galat & 7556,15 & 55 & 137,384 & & \\
Total & 10380,4 & 60 & & & \\
\hline
\end{tabular}

Berdasarkan hasil perhitungan analisis variansi dua jalur taksama maka dapat disimpulkan:

1) $\mathrm{F}_{\mathrm{a}}=7,737$ dan taraf signifikansi $5 \%$ didapatkan $F_{(\text {tabel })}=4,016$ sehingga $F_{a}>$ $\mathrm{F}_{\text {(tabel) }}$ yang menunjukkan $\mathrm{H}_{0 \mathrm{~A}}$ ditolak yang berarti terdapat perbedaan kecakapan berpikir rasional antara siswa yang diberikan metode socrates dengan siswa yang diberikan metode ekspositori.

2) $F_{b}=5,767$ dan taraf siknifikansi $5 \%$ $\mathrm{F}_{\text {(tabel) }}=3,164$ sehingga $\mathrm{F}_{\mathrm{b}}>\mathrm{F}_{\text {(tabel) }}$ yang menunjukkan $\mathrm{H}_{\mathrm{OB}}$ ditolak yang berati terdapat perbedaansiswa yang memiliki kecerdasan majemuk (kecerdasan logismatematis, interpersonal, dan linguistik) terhadap kecakapan berpikir rasional.

3) $F_{a b}=0,642$ dengan taraf signifikansi $5 \%$ diperoleh $\mathrm{F}_{\text {(tabel) }}=3,164 \mathrm{~F}_{\mathrm{ab}}<\mathrm{F}_{\text {(tabel) }}$ yang menunjukkan $\mathrm{H}_{0 \mathrm{AB}}$ diterima yang berarti tidak terdapat interaksi antara metode socrates dan kecerdasan majemuk siswa terhadap kecakapan berpikir rasional.

\section{Hasil dan Pembahasan}

Berdasarkan data yang sudah didapatkan dari hasil analisis, maka berikut adalah pembahasan dari ketiga hipotesis penelitian:

\section{Hipotesis pertama}

Berdasarkan hasil perhitungan anava dua jalur dengan sel tak sama memperlihatkan bahwaA(metode pembelajaran) didapatkan $\mathrm{F}_{\mathrm{a}}=7,737$ dan $F_{\text {(tabel) }}=4,016$ dengan signifikansi 5\%, sehinggan $\mathrm{F}_{\mathrm{a}}>\mathrm{F}_{\text {(tabel) }}$, maka $\mathrm{H}_{0 \mathrm{~A}}$ ditolak, hal ini berarti terdapat perbedaan kecakapan berpikir rasional antara siswa yang diberikan metode socrates dengan siswa yang diberikan metode ekspositori. Karena hanya terdapat dua metode pembelajaran tidak perlu melakukan uji lanjut anava antar baris, cukup dengan membandingkan rattan marginal untuk masing-masing metode pembelajaran.

Dilihat dari rataan marginal kecakapan berpikir rasional siswa lebih baik dengan menggunakan metode socrates dibandingkan dengan menggunakan metode ekspositori, karena pembelajaran socrates membimbing siswa dalam mengembangkan kemampuan dan pola pikir individual dikarenakan adanya percakapan, perdebatan dalam diskusi dan dihadapkan dalam suatu pokokbahasan serta berbagai pertanyaan yang membuat siswa berpikir secara jeli dan siswa dapat menemukan sendiri konsep pembelajaran matematika. Hal ini sesuai dengan Lammendola yang mengatakan metode socrates dapat membuat siswa berpikir secara rasional dan imiah, mengaktifkan siswa dalam proses pembelajaran dan dapat mengilustrasikan pengetahuannya serta menumbuhkan motivasi, rasa percaya diri dalam pemikirannya (Fisher, 2010).

Penelitian ini juga didukung dengan penelitian terdahulu yang telah dilakukan 
oleh Nadi Suprapto dan Muhammad Ihsan $M$ yang menyatakan bahwa hasil tes kecakapan berpikir rasional siswa yang menggunakan metode socrates mendapatkan rata-rata nilai yang lebih tinggi dibanding siswa yang berada dikelaskontrol yang menggunakan metode konvensional (Nurjannah, 2014). Sedangkan pada metode pembelajaran ekspositori, materi pembelajaran langsung diberikan kepada siswa. Ibrohim mengatakan pembelajaran ekspositori menempatkan guru sebagai peran yang lebih aktif dan siswa lebih pasif (Fahreza \& Husna, 2018; Hayati dkk., 2017). Metode pembelajaran ini diyakini dapat menyampaikan informasi secara cepat akan tetapi metode ini cenderung kurang mengembangkan penalaran dan kecakapannya, karena hanya mendapat informasi dari apa yang di sampaikan oleh guru, yang menyebabkan pembelajaran ekspositori belum bisa mendorong siswa mengembangkan kecakapan berpikir rasionalnya.

Berdasarkan hal itu siswa yang mendapatkan metode pembelajaran socrateskecakapan berpikir rasional lebih baik di banding siswa dengan metode ekspositori. Hasilnya juga telah sesuai dengan hipotesis penelitian, bahwa terdapat perbedaan kecakapan berpikir rasional antara siswa yang diberikan metode socratesdengan siswa yang diberikan metode ekspositori.

\section{Hipotesis kedua}

Hasil dari perhitungan anava dua jalur dengan sel tak sama memperihatkan bahwa terdapat perbedaan kecerdasan majemuk siswa terhadap kecakapan berpikir rasional siswa hingga perlu dilakukan uji komperensi ganda antar kolom menngunakan uji scheff'.
Berdasarkan hasil anava dua jalur denngan sel tak sama pada $\mathrm{B}$ (kecerdasan majemuk) diproleh $\mathrm{F}_{\mathrm{b}}=5,767$ dan $\mathrm{F}_{\text {(tabel) }}=$ 3,1649 sehingga $\mathrm{F}_{\mathrm{b}}=5,767>\mathrm{F}_{(\text {tabel })}=$ 3,1649 maka $\mathrm{H}_{0 \mathrm{~B}}$ ditolak, yang berarti terdapat perbedaan kecerdasan majemuk siswa terhadap kecakapan berpikir rasional.

Berdasarkan hasil uji komparasi ganda antar kolom pada masing-masing kategori kecerdasan majemuk, didapatkan bahwa siswa dengankecerdasan matematis logis mempunyai kecakapan berpikir rasional yang sama dengan siswa yang memiliki kecerdasan interpersonal, siswa dengan kecerdasan logis matematis dan siswa dengan kecerdasan interpersonal memiliki kecakapan berpikir rasional lebih baik dari siswa dengan kecerdasan linguistik.

Peristiwa ini dapat terjadi dikarenakan siswa memiliki kecerdasan logis matematis dan kecerdasan interpersonalakan lebih bertanggung jawab terhadap tugas yang diberikan dibandingkan dengan siswa yang memiliki kecerdasanlinguistik. Serta siswa dengan kecerdasan logis-matematis dan interpersonal cenderung lebih aktif dan memiliki semangat belajar yang tinggi, seperti banyak mengajukan pertanyaan yang bersifat analisis dan aktif dalam menjelaskan masalaha yang bersifat realistik. Kemudian siswa dengan kecerdasan linguistik memiliki semangat belajar yang lebih rendah dan kurang aktif dalam menyelesaikan masalah.

Sejalan dengan penelitian (Widyawati dkk., 2014) yang menyatakan siswa dengan kecardasan logis matematis dan siswa dengan kecerdasan interpersonal memiliki perestasi belajar lebih baik dari siswa yang memiliki kecerdasan linguistik. 


\section{Hipotesis Ketiga}

Hasil dari uji coba menyatakan tidak terjadi interaksi diantara penerapan metode socrates dengan kecerdasan majemuk siswa terhadap kecakapan berpikir rasional. Yang artinya metode pembelajaran yang digunakan tidak memiliki hubugan dengan kecerdasan logis matematis, interpersonal maupun linguistik.

Ditinjau memalui keseluruhan kecerdaasan majemuk terdapat pula perbedaan kecakapan berpikir rasional siswa pada setiap kategori kecerdasan. Siswa yang mempunyai kecerdasan logis matematis mempunyai kecakapan berpikir rasional yang sama dengan siswa dengan kecerdasan interpersonal, siswa dengan kecerdasan logis matematis mempunyai kecakapan berpikir rasiolal yang lebih baik dari siswa dengan kecerdasan linguistik, dan siswa dengan kecerdasan interpersonal mempunyia kecakapan berpikir rasiola dari siswa dengan kecerdasan linguistik.

Ketidak sesuaian penelitian dengan teori yang ada salah satunya dilandasi oleh ragam kecerdasan yang dimiliki setiap siswa. Dunn mengatakan jika seseorang mempunyai potensi, bakat dan kemampuan bawaan untuk di kembangkan, apabila pembelajaran dilakukan dengan cara yang sesuai dengan kemampuan bakat yang dimiliki, kemungkinan untuk menguasai subjek lebih besar (Pramudita, 2018). Walaupun metode pembelajaran yang dipakai berbeda pada masing-masing kelas, tetapi mempunyai tujuan utama yakni melihat pengaruh terhadap kecakapan berpikir rasional.

\section{Kesimpulan}

Berdasarkan analisis dari data dan pengujian hipotesis yang sudah dilaksanakan oleh peneiti, berikut merupakan kesimpulan dari penelitan yang telah dilaksanakan di SMPN 33 Bandar Lampung: Adanya perbedaan kecakapan berpikir rasional antara siswa yang diberikan metode socrates dengan siswa yang diberikan metode ekspositori, yang dimana siswa yang diberikan metode socrates kecakapan berpikir rasionalnya lebih baik dari pada siswa yang diberikan metode ekspositori dengan persentase rataaan marginal yakni $53,10 \%$ dan $46,89 \%$. Adanya perbedaan dampak antara siswa yang memiliki kecerdasan majemuk (kecerdasan logis-maematis, interpersonal, dan linguistik) terhadap kecakapan berpikir rasional siswa, yang dimana siswa dengan kecerdasan logis matematis dan interpersonal mempunyai keceakapan berpikir rasional yang lebih baik dibandingka dengan siswa yang mempunyai kecerdasan linguistik. Tidak adanya interaksi antara metode socrates dengan kecerdasan majemuk terhadap kecakapan berpikir rasional siswa.

Berikut merupakan beberapa saran dari peneliti berdasarkan hasil penelitian yang telah dilakukan: Siswa diharapkan dapat selalu aktif dalam proses pembelajaran matematika. Penelitian ini diharapkan dapat dilanjutkan oleh peneliti lain dengan menggali dan memperluas lingkup penelitian, sehingga dapat diteliti dengan metode pembelajaran lain yang lebih inovatif dengan memperhatikan baik dari variabel bebas lain yang turut mempengaruhi kecakapan berpikir rasional.

\section{Pustaka}

Assapari, M. M. (2014). Eksistensi bahasa Indonesia sebagai bahasa nasional dan perkembangannya di era globalisasi. Prasi, 9(18). 
Astuti, P. D. (2017). Sistem Informasi Penjualan Obat Pada Apotek Jati Farma Arjosari. Speed-sentra penelitian engineering dan edukasi, 3(4).

Astuti, R. N. (2012). Model Pembelajaran Connected Dalam Pembelajaran Sains Untuk Meningkatkan Keterampilan Berpikir Rasional Siswa MI/SD. Madrasah: Jurnal Pendidikan dan Pembelajaran Dasar, 3(2).

Budiman, H. (2017). Peran teknologi informasi dan komunikasi dalam pendidikan. Al-Tadzkiyyah: Jurnal Pendidikan Islam, 8(1), 31-43.

Cahyono, A., Yunarti, T., \& Widyastuti, W. (2015). Efektivitas Pembelajaran Socrates Kontekstual dalam Mengembangkan Kemampuan Berpikir Kritis Matematis Siswa. Jurnal Pendidikan Matematika Unila, 3(6).

Elfiadi, E. (2017). Kecerdasan Jamak Pada Anak Usia Dini. Itqan: Jurnal IlmuIlmu Kependidikan, 8 (2), 35-52.

Ernawati, E., \& Nasir, A. M. (2018). Efektivitas Metode Pembelajaran Socrates Kontekstual Berbasis Gaya Kognitif terhadap Hasil Belajar Statistik Dasar. Proximal: Jurnal Penelitian Matematika dan Pendidikan Matematika, 1(2).

Estuningsih, W. (2016). Penerapan Model Pembelajaran Children Learning in Science untuk Meningkatkan Keterampilan Berpikir Rasional Siswa Pada Materi Penyesuaian Makhluk Hidup Terhadap Lingkungannya Kelas VA SDN Sidotopo IV/51 Surabaya. Jurnal Penelitian Pendidikan Guru Sekolah Dasar, 3(2).
Fahreza, F., \& Husna, N. (2018). Pengaruh Strategi Pembelajaran Terhadap Hasil Belajar Ips Siswa Kelas V SD Negeri Paya Peunaga Kabupaten Aceh Barat. Bina Gogik: Jurnal Ilmiah Pendidikan Guru Sekolah Dasar, 4(2).

Fisher, C. (2010). Discussion, participation and feedback in online courses. ISECON Proceedings, 27, 1382.

HASANAH, U. N., Thahir, A., Komaruddin, K., \& Rahmahwaty, R. (t.t.). MURDER Learning and Self Efficacy Models: Impact on Mathematical Reflective Thingking Ability. Journal for the Education of Gifted Young Scientists, 7(4), 1123-1135.

Hayati, S. N., Hikmawati, H., \& Wahyudi, W. (2017). Pengaruh model pembelajaran inkuiri dengan menggunakan media simulasi terhadap hasil belajar fisika siswa kelas X MIA SMAN 1 Lingsar Lombok Barat Tahun Pelajaran 2016/2017. Jurnal Pendidikan Fisika dan Teknologi, 3(1), 48-54.

Madyawati, L., \& Si, M. (2016). Strategi pengembangan bahasa pada anak. Kencana.

Nasution, A. R. (2019). Meningkatkan Hasil Belajar Melalui Strategi Kekuatan Dua Kepala (The Power Of Two) Dalam Pembelajaran Matematika Materi Logaritma Siswa. Jurnal MathEducation Nusantara, 2(1), 7-10.

Nurjannah, A. (2014). Pengaruh Penerapan Pembelajaran Socrates Terhadap Keterampilan Berpikir Kritis dalam Pembelajaran Fisika pada Materi Hukum Newton. Inovasi Pendidikan Fisika, 3(2). 
Nurohman, S. (2006). Penerapan Pendekatan Sains-teknologimasyarakat (Stm) Dalam Pembelajaran Ip a Seba Gai Upa Ya Peningkatan Life Skills Peserta Didik. Majalah Ilmiah Pembelajaran, 2(1).

Pramudita, R. (2018). Pengaruh Model Pembelajaran Quantum Teaching Terhadap Hasil Belajar Kognitif Peserta Didik Ditinjau dari Kecerdasan Majemuk. Desimal: Jurnal Matematika, 1(2), 245-255.

Ramli, M. (2015). Hakikat Pendidik Dan Peserta Didik. Tarbiyah Islamiyah: Jurnal Ilmiah Pendidikan Agama Islam, 5(1).

Salamah, F. N., \& Amelia, R. (2019). Upaya Meningkatkan Self Confidence Siswa SMK Menggunakan Pendekatan Open Ended. Jurnal Cendekia: Jurnal Pendidikan Matematika, 3(1), 2833.

Septiana, K. G., \& Ikhsan, J. (2017). Pengaruh penerapan multiple intelligences dengan model PBL terhadap pemahaman konsep dan kemampuan berpikir kreatif. Jurnal Edukasi Matematika Dan Sains, 5(1), 43-52.

Sholeh, K. (2016). Kecerdasan Majemuk Berorientasi pada Partisipasi Peserta Didik. Pustaka Pelajar.

Sholihah, D. A., \& Shanti, W. N. (2017). Diposisi Berpikir Kritis Matematis Dalam Pembelajaran Menggunakan Metode Socrates. Jurnal Karya Pendidikan Matematika, 4(2), 1-9.

Sinta, S. (2017). Pengaruh Model pembelajaran Kooperatif Learning Tipe Think Pair Share Terhadap
Peningkatan Berpikir Kritis Siswa Pada Mata Pelajaran PAI: Penelitian Kelas VIII C SMP ALHasan Kec. Panyileukan Kota Bandung. UIN Sunan Gunung Djati Bandung.

Syukur, S. D., Kadir, K., Bey, A., \& Prajono, R. (2019). Pengaruh Penerapan Metode Pembelajaran Socrates Terhadap Kemampuan Berpikir Kreatif Matematis Siswa Kelas VIII MTs Negeri 2 Bombana. Jurnal Pendidikan Matematika, 10(2), 172-182.

Widyawati, S., Mardiyana, M., \& Iswahyudi, G. (2014). Eksperimentasi Model Pembelajaran Kooperatif Tipe Two Stay Two Stray (TSTS) Dan Numbered Heads Together (NHT) Ditinjau Dari Kecerdasan Majemuk Peserta Didik. Jurnal Pembelajaran Matematika, 2(9).

Yasin, M., \& Netriwati, N. (2019). Analisis Kesulitan Belajar: Dampak Latar Belakang Kejuruan ditinjau dari Proses Pembelajaran Matematika Perguruan Tinggi. Desimal: Jurnal Matematika, 2(1), 59-67.

Yulisa, Y., Yunarti, T., \& Widyastuti, W. (2015). Disposisi Berpikir Kritis Matematis Dalam Pembelajaran Dengan Metode Socrates Dan Pendekatan Kontekstual. Jurnal Pendidikan Matematika Unila, 3(3).

Zulva, R. (2016). Hubungan antara Keterampilan Berpikir Rasional Siswa SMA Dengan Hasil Belajar Dalam Pembelajaran Kooperatif Menggunakan Constructive Feedback. Jurnal Ilmiah Pendidikan Fisika Al-Biruni, 5(1), 61-69. 